\title{
Genotoxic and Histopathological Effects of Water Pollution on Clarias gariepinus Fish at Fayoum Governorate, Egypt
}

\author{
Khalid H. Zaghloul, Heba A. Mohamed, Abdulkareem M. Abdullatef, Mohamed W. Khalil \\ Department of Zoology, Faculty of Science, Fayoum University, Fayoum, Egypt \\ Email:khz00@fayoum.edu.eg
}

How to cite this paper: Zaghloul, K.H., Mohamed, H.A., Abdullatef, A.M. and Khalil, M.W. (2020) Genotoxic and Histopathological Effects of Water Pollution on Clarias gariepinus Fish at Fayoum Governorate, Egypt. Natural Resources, 11, 499519.

https://doi.org/10.4236/nr.2020.1111029

Received: May 21, 2020

Accepted: November 16, 2020

Published: November 19, 2020

Copyright $\odot 2020$ by author(s) and Scientific Research Publishing Inc. This work is licensed under the Creative Commons Attribution International License (CC BY 4.0).

http://creativecommons.org/licenses/by/4.0/

\begin{abstract}
Increasing land reclamation in El-Fayoum governorate has led to increase the amount of drainage water that discharged without prior treatments to two main drains, El-Wadi and El-Bats drainages loaded by salts and heavy metals. So, the present investigation aims to evaluate quality of water samples collected from a branch of the river Nile (El-Lahon canal) and the main drains (El-Bats and El-Wadi) at Fayoum governorate on some biomarkers of the Nile catfish; Clarias gariepinus inhabiting the studied degradable aquatic habitats. Water and nighty fish samples colleted from the different studied sites of collection by the help of fishermen for physicochemical analyes of water and fish biochemical analyses and histopathological alteration. Results revealed highly significant differences at $\mathrm{P} \leq 0.01$ with the highest water ammonia, nitrite, heavy metals $(\mathrm{Cu}, \mathrm{Zn}, \mathrm{Pb}$ and $\mathrm{Cd})$ and lowest dissolved oxygen content accompanied by metals bioaccumulation in vital organs of fish collected from the main drains (El-Bats and El-Wadi) in comparision with that collected from the studied branch of the river Nile. Higher bioaccumulation of the studied heavy metals in gills, liver, kidney and muscles of Clarias gariepinus collected from the main drains significant increase in serum glucose, liver and kidney functions, disturbance in protein profile of fish collected from the studied main drains than that of fish collected from the river Nile branch, El-Lahon that showed more or less normal values. Moreover, histopathological alterations in gills, liver, kidneys and clear DNA strand breaks in fish liver cells increased statistically in Clarias gariepinus collected from ElFayoum drainage canals. Generally, the results highlights on the importance of taking action through the responsible authorities towards quality of the drainage water that fed fish farms by law that could play a role as a main source of protein for human beings.
\end{abstract}




\section{Keywords}

Drainage Water, Catfish, Genotoxicity, Histopathology, Biochemical Changes

\section{Introduction}

Fish are important members of aquatic ecosystems and an important source of human food. However, fish distribution data in Egypt indicate a reduction in the commercially desirable fish species as the water conditions deteriorate. Agricultural, waste municipal and industrial effluents discharged directly to the natural water resources have been found to cause heavy fish mortality due to hypoxia, high levels of organic substances, inorganic salts and heavy metals [1] [2].

Two major drains called El-Bats and El-Wadi drains at El-Fayoum governorate receive agricultural drainage water, waste municipal and industrial effluents without prior treatments. The drainage water was estimated as 390 million cubic meters annually [3] [4] [5]. Due to the regulation rules for use of water resources in El-Fayoum province, fish farms which mainly established around El-Bats and El-Wadi drainage canals are allowed only to use water from the drainage network around [6]. Thus, these fish farms using agricultural drainage water may face the danger of negative effects on their cultured fish species [7] [8] [9].

Agricultural run-offs have cumulatively negative effects on the environmental quality of water in which decreased biodiversity and accidental fish die-offs have occurred. Water quality of the aquatic ecosystem is considered as the main factor controlling the state of health and disease in both cultured and wild fish [3] [4] [10]. Among the various toxic pollutants, heavy metals represent a very interesting group of elements due to their strong impact on stability of aquatic ecosystems, bioaccumulation in living organisms [11], toxicity persistence and tendency to accumulate in water and sediments. Heavy metals are used as indicators of pollution in the ecosystem, and have recently came to the forefront of dangerous substances causing serious health hazards for humans and other organisms [12] [13].

The exposure of aquatic organisms to environmental contamination often results in genotoxic insult, either via direct genotoxicity, or through the induction of cellular or oxidative stress. Fish are considered as common model species to evaluate the health of aquatic ecosystems because pollutants build up in the food chain and are responsible for adverse effects including death in the aquatic systems. Pollutants with a genotoxic potential for the aquatic organisms are of serious concern since they can bind to DNA molecules and provoke a damaging chain of biological changes such as impaired enzyme functions or general metabolism, cytotoxicity, immunotoxicity, inhibition of growth and/or carcinogenesis [14]. Moreover, histopathological changes in cells, tissues and organs used as biomarkers for more benefits; Confirmation of measurements evaluated by chemical and biochemical analysis, and permitting researchers to examine specific tar- 
get organs and cells affected by exposure to toxicants. Paithane, et al., [15], pointed out that the histopathology biomarker is a higher level response following chemical and cellular interaction.

Therefore, the present study was conducted to evaluate the quality of water as well as provide comparable biomarkers data of Clarias gariepinus collected from three different degradable aquatic habitats (Branch of the river Nile and the main drains at El-Fayoum governorate, El-Bats and El-Wadi). The aforementioned aim of the present study achieved through carrying out the residual heavy metals $(\mathrm{Cu}, \mathrm{Zn}, \mathrm{Pb}$ and $\mathrm{Cd}$ ) in some selected vital organs of fish (Gills, liver, kidney and muscles), serum glucose, liver and kidney functions and protein profile. In addition to recognize DNA damage degree in liver cells using comet assay and follw up histopathological alterations in gills, liver and kidney of the studied fish.

\section{Materials and Methods}

The present field study was carried out on water and Nile catfish; Clarias gariepinus samples collected directly from three different studied aquatic habitats at El-Fayoum governorate: Site (1): Area of the river Nile at Fayoum governorate, El-Lahon canal. Site (2): El-Bats drainage canal at El-Fayoum governorate where agricultural and waste municipal water discharged. Site (3): El-Wadi drainage canal at El-Fayoum governorate where agricultural drainage water discharged.

Water and fish sampling: Water and fish samples were collected from each site for the following investigations.

1) Water sampling and analysis: Water samples were collected approximately $20 \mathrm{~cm}$ below the surface water as reported by Ndimele and Kumolu-Johnson, [16], and kept in $500 \mathrm{ml}$ sterile plastic containers. Samples were filtered and acidified with $10 \% \mathrm{HNO}_{3}$ for preservation, placed in an ice bath and brought to the laboratory.

a) Physicochemical analysis of water: The water samples collected from different locations in the studied ecosystems were subjected to a number of physicochemical analyses as mentioned below:-

- $\mathrm{pH}$ was measured at the sampling site by means of a pocket-pH meter (Micro Checkit $^{\circledast} \mathrm{pH}+$, Lovibond, England).

- Dissolved oxygen ( $\mathrm{mg} / \mathrm{l})$ concentration was determined at the sampling site by means of Oxygen meter (model, YSI58).

- Salinity was measured by using a salinity-conductivity meter (model, YSI 58).

- Total hardness and total alkalinity were measured by titration method according to the American Public Health Association standard methods [17].

- Ammonia and nitrite were measured according to the method described by the American Public Health Association standard methods [17].

b) water analysis for heavy metals: Heavy metal concentrations in water were determined by atomic absorption spectrophotometer (Perkin Elmer, 2280). The samples were prepared and analyzed sequentialy for zinc, copper, lead and 
cadmium according to APHA [17].

2) Fish sampling and analysis: A total number of 90 adult fish of Nile catfish; Clarias gariepinus (30 fish/site), fishes were collected with the help of local fishermen for the following analyses:

a) Residual heavy metals in some selected vital organs of the studied Fishes:

Fish were dissected for its gills, liver, kidney and muscles tissues then, washed with de-ionized water, put in cleaned plastic bags and stored frozen until analysis was carried out. Known weight of the prepared tissue sample (wet weight) was dried at $65^{\circ} \mathrm{C}$ until they reached to a constant weight. All samples were ashed in a muffle furnace for 6 hours at $650^{\circ} \mathrm{C}$. The tissue ash were then dissolved and diluted to $25 \mathrm{ml}$ with $0.1 \mathrm{~N}$ hydrochloric acid. Heavy metal concentrations were determined using an atomic absorption spectrophotometer according to APHA [17].

Heavy metal concentration $(\mu \mathrm{g} / \mathrm{g})=$ reading of atomic absorption $\times$ volume of diluted solution/Weight of sample (g).

b) Blood sampling and biochemical analysis: The fishes, Clarias gariepinus for blood analysis were brought to the laboratory alive in an aerated tank. Blood samples were withdrawn from the arterial caudalies, sucked into the syringes. Moreover, serum was obtained by centrifugation (At $5000 \mathrm{rpm}$ for 12 minutes) and stored at $-20^{\circ} \mathrm{C}$ for further analysis. The blood sample subjected to the following examinations:

- Biochemical analysis:

i) Serum analysis:

Serum glucose was measured by using BIOme-rieux kit according to the method described by Trinder [18]. Aminotransferase: Serum Aspartate aminotransferase (AST) and Alanine aminotransferase (ALT) activities were estimated colorimetrically as described by Reitmans and Frankel [19]. Serum ALP activity was determined using the method of Tietz, et al., [20]. Serum creatinine by the method of Tietz, [21]. Serum Uric acid the method described by Tietz, [22]. Serum total protein content was determined by Biuret test [23]. Serum albumin according to the procedure of Doumas et al. [24]. Serum globulin calculated as the difference between plasma total protein and albumin.

ii) DNA damage assay:

Isolation of cells from fish liver after fishing from different sites of collection, the livers of fish collected from the different studied aquatic habitat were dissected and placed in eppendorf tubes containing ice cold PBS. The liver tissues then washed and minced with scissors to release single cells from liver tissues in PBS buffer with $20 \mathrm{mM}$ EDTA. The layer with cell suspension was separated in a new tube after settling of tissues pieces and cell debris from the sample. The cells were counted, washed in ice cold PBS and adjusted to $1 \mathrm{x} 105$ cells/ ml. Quantification of DNA damage by single cell gel electrophoresis assay carried out according to Kumaravel and Jha [25].

3) Histological studies: Samples for histological evaluation of gills, liver and 
kidney tissues of the fish were obtained by dissection and then fixed in Bouin's fixative for $24 \mathrm{~h}$. After dehydration in graded concentrations of ethanol, the samples were embedded in paraffin wax. Histological sections of $4 \mu \mathrm{m}$ thickness were stained with Haematoxylin and Eosin. Sections were reviewed by light microscopy Leitz Laborlux S and photographed (Sony DKC-CM30).

4) Statistical analysis: The results were statistically analyzed using analysis of variance (F-test) followed by Duncan's multiple range test to determine differences in means using Statistical Analysis Systems, Version 6.2 [26].

\section{Results}

\section{Water quality:}

Physicochemical properties of water from the different studied aquatic ecosystems are illustrated in Table 1. It is clear that, analysis of variance (F-values) showed highly significant differences $(\mathrm{p}<0.01)$ in the values of $\mathrm{pH}$, oxygen content, total hardness, total alkalinity, salinity, ammonia and nitrite among the different studied sites (F-values $=79.9,386,401,102,331,516$ and 291 respectively). It is evident from Table 1 that, the highest value of dissolved oxygen $(7.89 \pm 0.02)$ was recorded at the studied area of the river Nile at Fayoum governorate and decreased in the main drainage canals, El-Bats and El-Wadi (5.75 \pm 0.09 and $5.36 \pm 0.07)$ respectively.

The present data (Table 1) also showed high values of water ammonia (4.19 \pm 0.11 and $3.15 \pm 0.11$ respectively) and nitrite $(0.65 \pm 0.03,0.41 \pm 0.01$ respectively) in water samples collected from El-Wadi and El-Bats drains at El-Fayoum governorate and the lowest ammonia and nitrite values were recorded at the studied site of the river Nile at Fayoum governorate $(0.28 \pm 0.02$ and $0.03 \pm$ 0.004 respectively). However, higher water salinity was recorded at El-Bats drain and El-Wadi drains $(10.5 \pm 0.42 \mathrm{~g} / \mathrm{l}$ and $3.87 \pm 0.27 \mathrm{~g} / \mathrm{l}$ respectively).

\section{Residual heavy metals:}

Values of water heavy metals (zinc, copper, lead and cadmium) and their bioaccumulation in the studied vital organs of the Nile catfish, Clarias gariepinus are given in Table 2. It is clear that, there were highly significant differences ( $\mathrm{p}$ $<0.01)$ in all studied heavy metal concentrations among the different studied sites.

Table 1. Quality of water collected from branch of the river Nile and the main drains at El-Fayoum governorate, Egypt.

\begin{tabular}{|c|c|c|c|c|c|c|c|}
\hline $\begin{array}{l}\text { Studied Sites } \\
\text { of Collection }\end{array}$ & $\mathrm{pH}$ & $\begin{array}{c}\text { Dissolved } \\
\text { oxygen mg/l }\end{array}$ & $\begin{array}{l}\text { Total Hardness } \\
\text { as } \mathrm{CaCO}_{3} \mathrm{mg} / 1\end{array}$ & $\begin{array}{l}\text { Total alkalinity } \\
\text { as } \mathrm{CaCO}_{3} \mathrm{mg} / \mathrm{I}\end{array}$ & Salinity $\mathrm{g} / \mathrm{l}$ & $\mathrm{NH}_{3} \mathrm{mg} / \mathrm{l}$ & $\mathrm{NO}_{2} \mathrm{mg} / \mathrm{l}$ \\
\hline $\begin{array}{l}\text { El-Lahon canal (Branch } \\
\text { of the river Nile) }\end{array}$ & $7.57 \pm 0.03 \mathrm{C}$ & $7.89 \pm 0.02 \mathrm{~A}$ & $141 \pm 1.69 \mathrm{C}$ & $113 \pm 4.74 \mathrm{C}$ & $0.084 \pm 0.003 \mathrm{C}$ & $0.28 \pm 0.02 \mathrm{C}$ & $0.03 \pm 0.004 \mathrm{C}$ \\
\hline El-Bats drainage canal & $8.30 \pm 0.04 \mathrm{~A}$ & $5.36 \pm 0.07 \mathrm{C}$ & $427 \pm 10.9 \mathrm{~A}$ & $290 \pm 1.32 \mathrm{~A}$ & $10.5 \pm 0.42 \mathrm{~A}$ & $3.15 \pm 0.11 \mathrm{~B}$ & $0.41 \pm 0.01 \mathrm{~B}$ \\
\hline El-Wadi drainage canal & $8.05 \pm 0.04 \mathrm{~B}$ & $5.75 \pm 0.09 \mathrm{~B}$ & $385 \pm 7.3 \mathrm{~B}$ & $256 \pm 1.54 \mathrm{~B}$ & $3.87 \pm 0.27 \mathrm{~B}$ & $4.19 \pm 0.11 \mathrm{~A}$ & $0.65 \pm 0.03 \mathrm{~A}$ \\
\hline F-values & $79.9^{* *}$ & $386^{* *}$ & $401^{* *}$ & $102^{* *}$ & $331^{* *}$ & $516^{* *}$ & $291^{* *}$ \\
\hline
\end{tabular}

Data are represented as means of eight samples \pm Sterr. Means with the same letter for each parameter are not significantly different, otherwise they do (SAS, 2000). ${ }^{* *}$ Highly Significant difference $(\mathrm{P}<0.01)$. 
Table 2. Residual heavy metals concentrations in water $(\mathrm{mg} / \mathrm{l})$ and some selected vital organs ( $\mathrm{mg} / \mathrm{kg}$ dry weight) of Clarias gariepinus collected from branch of the river Nile and the main drains at El-Fayoum governorate, Egypt.

\begin{tabular}{|c|c|c|c|c|c|}
\hline Studied $\mathrm{m}$ & als $\begin{array}{r}\begin{array}{r}\text { Studied sites of } \\
\text { collection }\end{array} \\
\text { allon }\end{array}$ & $\begin{array}{l}\text { El-Lahon canal } \\
\text { (Branch of the } \\
\text { river Nile) }\end{array}$ & $\begin{array}{l}\text { El-Bats drainage } \\
\text { canal }\end{array}$ & $\begin{array}{l}\text { El-Wadi drainage } \\
\text { canal }\end{array}$ & F-value \\
\hline \multirow{5}{*}{ Zinc } & $\begin{array}{c}\text { Water } \\
\text { P.1. }=5.0 \mathrm{mg} / 1\end{array}$ & $0.65 \pm 0.04 \mathrm{C}$ & $3.35 \pm 0.14 \mathrm{~A}$ & $2.9 \pm 0.13 \mathrm{~B}$ & $163^{* *}$ \\
\hline & Gills & $10.18 \pm 0.34 \mathrm{C}$ & $37.05 \pm 1.41 \mathrm{~A}$ & $33.95 \pm 0.90 \mathrm{~B}$ & $220^{* *}$ \\
\hline & Liver & $11.68 \pm 0.42 \mathrm{~B}$ & $31.77 \pm 1.32 \mathrm{~A}$ & $33.32 \pm 0.61 \mathrm{~A}$ & $189^{* *}$ \\
\hline & Kidney & $7.13 \pm 0.21 \mathrm{C}$ & $28.25 \pm 2.47 \mathrm{~A}$ & $21.48 \pm 1.81 \mathrm{~B}$ & $37^{* *}$ \\
\hline & $\begin{array}{c}\text { Muscles } \\
\text { P.1. }=40 \mathrm{ppm}\end{array}$ & $1.25 \pm 0.08 \mathrm{C}$ & $3.10 \pm 0.25 \mathrm{~A}$ & $2.85 \pm 0.10 \mathrm{~A}$ & $72^{* *}$ \\
\hline \multirow{5}{*}{ Copper } & $\begin{array}{c}\text { Water } \\
\text { P.1. }=1.0 \mathrm{mg} / 1\end{array}$ & $0.04 \pm 0.003 \mathrm{C}$ & $0.47 \pm 0.02 \mathrm{~A}$ & $0.38 \pm 0.02 \mathrm{~B}$ & $289^{* *}$ \\
\hline & Gills & $1.60 \pm 0.46 \mathrm{~B}$ & $2.91 \pm 0.1 \mathrm{~A}$ & $2.38 \pm 0.16 \mathrm{~A}$ & $84^{* *}$ \\
\hline & Liver & $3.28 \pm 0.24 \mathrm{C}$ & $14.59 \pm 0.41 \mathrm{~A}$ & $11.79 \pm 0.42 \mathrm{~B}$ & $256^{* *}$ \\
\hline & Kidney & $2.1 \pm 0.07 \mathrm{~B}$ & $10.55 \pm 0.35 \mathrm{~A}$ & $10.64 \pm 0.27 \mathrm{~A}$ & $353^{* *}$ \\
\hline & $\begin{array}{c}\text { Muscles } \\
\text { P.1. }=20 \mathrm{ppm}\end{array}$ & $0.63 \pm 0.09 \mathrm{C}$ & $1.88 \pm 0.15 \mathrm{~A}$ & $1.10 \pm 0.10 \mathrm{~B}$ & $33^{* *}$ \\
\hline \multirow{5}{*}{ Lead } & $\begin{array}{c}\text { Water } \\
\text { P.1. }=0.05 \mathrm{mg} / 1\end{array}$ & $0.025 \pm 0.005 \mathrm{C}$ & $0.31 \pm 0.015 \mathrm{~B}$ & $0.41 \pm 0.01 \mathrm{~A}$ & $259^{* *}$ \\
\hline & Gills & $0.173 \pm 0.008 \mathrm{C}$ & $1.21 \pm 0.18 \mathrm{~B}$ & $1.94 \pm 0.09 \mathrm{~A}$ & $59^{* *}$ \\
\hline & Liver & $0.178 \pm 0.01 \mathrm{C}$ & $0.48 \pm 0.03 \mathrm{~B}$ & $0.88 \pm 0.10 \mathrm{~A}$ & $33^{* *}$ \\
\hline & Kidney & $0.025 \pm 0.012 \mathrm{C}$ & $0.31 \pm 0.008 \mathrm{~B}$ & $0.42 \pm 0.04 \mathrm{~A}$ & $64^{* *}$ \\
\hline & $\begin{array}{c}\text { Muscles } \\
\text { P.1. }=0.6 \mathrm{ppm}\end{array}$ & $0.067 \pm 0.008 \mathrm{C}$ & $0.165 \pm 0.019 \mathrm{~B}$ & $0.58 \pm 0.10 \mathrm{~A}$ & $18.3^{* *}$ \\
\hline \multirow{5}{*}{ Cadmium } & $\begin{array}{c}\text { Water } \\
\text { P.1. }=0.01 \mathrm{mg} / 1\end{array}$ & $0.002 \pm 0.0003 \mathrm{C}$ & $0.053 \pm 0.003 \mathrm{~A}$ & $0.032 \pm 0.001 \mathrm{~B}$ & $162^{* *}$ \\
\hline & Gills & $0.022 \pm 0.004 \mathrm{C}$ & $0.39 \pm 0.06 \mathrm{~A}$ & $0.25 \pm 0.044 \mathrm{~B}$ & $16^{* *}$ \\
\hline & Liver & $0.038 \pm 0.005 \mathrm{C}$ & $0.256 \pm 0.02 \mathrm{~A}$ & $0.156 \pm 0.02 \mathrm{~B}$ & $51^{* *}$ \\
\hline & Kidney & $0.015 \pm 0.003 \mathrm{C}$ & $0.68 \pm 0.08 \mathrm{~A}$ & $0.30 \pm 0.04 \mathrm{~B}$ & $39^{* *}$ \\
\hline & $\begin{array}{c}\text { Muscles } \\
\text { P.1. }=0.5 \text { ppm }\end{array}$ & N.D. & $0.065 \pm 0.01 \mathrm{~A}$ & $0.036 \pm 0.01 \mathrm{~B}$ & $12^{* *}$ \\
\hline
\end{tabular}

Data are represented as means of eight samples \pm Sterr. P.l. = Permissible level in fish tissues for human consumption according to WHO (1998). N.D. = Not Detectable. Means with the same letter for each parameter in each raw are not significantly different, otherwise they do (SAS, 2000). ${ }^{*}$ Highly Significant difference $(\mathrm{P}<0.01)$.

The results declared that in presence of the industrial and agricultural effluents which discharged directly to the main drains at El-Fayoum governorate (ElBats and El-Wadi drains), the concentrations of zinc, copper, lead and cadmium in water were higher than that of water samples collected from the branch of the river Nile (El-Lahon canal) at Fayoum governorate and exhibit the following order: 
Zinc: El-Bats drain > El-Wadi drain > River Nile Branch (El-Lahon)

Copper: El-Bats drain > El-Wadi drain > River Nile Branch (El-Lahon)

Lead: El-Wadi drain > El-Bats drain > River Nile Branch (El-Lahon)

Cadmium: El-Bats drain > El-Wadi drain > River Nile Branch (El-Lahon)

It is clear from the present results also that the highest concentrations of the different recorded heavy metals were found in fish tissues collected from El-Bats and El-Wadi drains at El-Fayoum governorate and exhibit the following order:

Gills $>$ liver $>$ kidney $>$ muscles in case of zinc bioaccumulation;

liver $>$ kidneys $>$ gills $>$ muscles in case of copper bioaccumulation.

Gills $>$ liver $>$ kidney $>$ muscles in case of lead bioaccumulation;

Gills $>$ kidney $>$ liver $>$ muscles in case of cadmium bioaccumulation.

The results also declared that the lowest concentrations of the studied heavy metals were recorded in tissues of fish collected from the river Nile branch at El-Fayoum governorate (El-Lahon canal).

\section{Serum constituents}

Data concerning the changes in serum glucose, aspartate amino transferase (AST), alanine amino transferase (ALT) and alkaline phosphatase activities (ALP), creatinine and uric acid of the Nile catfish; Clarias gariepinus collected from the different studied aquatic habitats, the branch of the river Nile and the main drains at Fayoum governorate are given in Table 3.

It is clear that, there is highly significant differences in the studied serum constituents of fish collected from the different studied habitats with the highest values in fish collected from El-Bats and El-Wadi drain canals compared to that of fish collected from the river Nile branch, El-Lahon at El-Fayoum governorate.

\section{Serum Protein Profile:}

Data of serum protein profile, total protein, albumin, globulin and A/G ratio of the studied fish species; Clarias gatiepinus collected from the river Nile branch, El-Lahon and the main drains at El-Fayoum governorate are given in Table 4. Results of serum protein profile of Clarias gatiepinus showed highly significant differences, with the highest values in serum total protein, albumin and globulin of fish collected from El-Bats and El-Waid drains, but the lowest values were recorded in serum samples of fish collected from the unpolluted

Table 3. Serum constituents of Clarias gariepinus collected from branch of the river Nile and the main drains at El-Fayoum governorate, Egypt.

\begin{tabular}{ccccccc}
\hline Studied Sites of Collection & $\begin{array}{c}\text { Glucose } \\
(\mathrm{mg} / 100 \mathrm{ml})\end{array}$ & $\begin{array}{c}\text { AST } \\
(\mathrm{u} / \mathrm{l})\end{array}$ & $\begin{array}{c}\text { ALT } \\
(\mathrm{u} / \mathrm{l})\end{array}$ & $\begin{array}{c}\text { ALP } \\
(\mathrm{u} / \mathrm{l})\end{array}$ & $\begin{array}{c}\text { Creatinine } \\
(\mathrm{mg} / \mathbf{1 0 0} \mathrm{ml})\end{array}$ & $\begin{array}{c}\text { Uric acid } \\
(\mathrm{mg} / \mathbf{1 0 0} \mathrm{ml})\end{array}$ \\
\hline $\begin{array}{c}\text { El-Lahon canal } \\
\text { (Branch of the river Nile) }\end{array}$ & $44.38 \pm 3.11 \mathrm{~B}$ & $18.25 \pm 1.92 \mathrm{C}$ & $16.25 \pm 1.08 \mathrm{~B}$ & $21.63 \pm 1.24 \mathrm{C}$ & $0.25 \pm 0.05 \mathrm{C}$ & $3.85 \pm 0.16 \mathrm{C}$ \\
El-Bats drainage canal & $158.5 \pm 27.7 \mathrm{~A}$ & $232 \pm 15.5 \mathrm{~A}$ & $45 \pm 3.8 \mathrm{~A}$ & $47.9 \pm 3.1 \mathrm{~A}$ & $2.19 \pm 0.30 \mathrm{~A}$ & $39.4 \pm 3.15 \mathrm{~A}$ \\
El-Wadi drainage canal & $112 \pm 10.4 \mathrm{~A}$ & $58.4 \pm 3.5 \mathrm{~B}$ & $48.8 \pm 2.42 \mathrm{~A}$ & $40.3 \pm 1.86 \mathrm{~B}$ & $1.49 \pm 0.27 \mathrm{~B}$ & $10.43 \pm 1.09 \mathrm{~B}$ \\
F-values & $\mathbf{1 1 . 2 ^ { * * }}$ & $\mathbf{1 5 1}^{* *}$ & $\mathbf{4 4}^{* *}$ & $\mathbf{3 8}^{* *}$ & $\mathbf{1 8}^{* *}$ & $\mathbf{9 6}$ \\
\hline
\end{tabular}

Data are represented as means of eight samples \pm Sterr. Means within the same column, with the same letter for each parameter are not significantly different, otherwise they do (SAS, 2000). ${ }^{* *}$ Highly significant difference at $\mathrm{P} \leq 0.01$. 
Table 4. Serum protein profile of Clarias gariepinus collected from branch of the river Nile and the main drains at El-Fayoum governorate, Egypt.

\begin{tabular}{ccccc}
\hline Studied Sites of Collection & $\begin{array}{c}\text { Total protein } \\
(\mathrm{g} / 100 \mathrm{ml})\end{array}$ & $\begin{array}{c}\text { Albumin } \\
(\mathrm{g} / 100 \mathrm{ml})\end{array}$ & $\begin{array}{c}\text { Globulin } \\
(\mathrm{g} / 100 \mathrm{ml})\end{array}$ & A/G ratio \\
\hline $\begin{array}{c}\text { El-Lahon canal } \\
\text { (Branch of the river Nile) }\end{array}$ & $2.45 \pm 0.22 \mathrm{C}$ & $1.98 \pm 0.15 \mathrm{C}$ & $0.46 \pm 0.08 \mathrm{C}$ & $4.84 \pm 0.59 \mathrm{~A}$ \\
El-Bats drainage canal & $5.30 \pm 0.30 \mathrm{~A}$ & $3.47 \pm 0.15 \mathrm{~A}$ & $1.74 \pm 0.16 \mathrm{~A}$ & $2.10 \pm 0.12 \mathrm{C}$ \\
El-Wadi drainage canal & $3.38 \pm 0.12 \mathrm{~B}$ & $2.63 \pm 0.16 \mathrm{~B}$ & $0.75 \pm 0.08 \mathrm{~B}$ & $3.90 \pm 0.60 \mathrm{~B}$ \\
F-values & $\mathbf{4 1 *}$ & $\mathbf{2 3}^{* *}$ & $\mathbf{3 4}^{* *}$ & $\mathbf{8 . 9 5}^{* *}$ \\
\hline
\end{tabular}

Data are represented as means of eight samples \pm Sterr. Means within the same column, with the same letter for each parameter are not significantly different, otherwise they do (SAS, 2000). ${ }^{*}$ Highly significant difference at $\mathrm{P} \leq 0.01$.

branch of the river Nile, El-Lahon at Fayoum governorate. However, serum A/G ratio of Clarias gatiepinus collected from El-Bats and El-Wadi drains revealed significant decrease $(F-v a l u e=8.95)$ than that calculated for fish collected from the river Nile branch at Fayoum governorate.

\section{Genotoxicity study, Comet assay:}

The present study demonstrates genotoxic and mutagenic damage in fish liver cells (Figure 1 and Table 5). Results of comet assay using single cell of fish livers proved to be a sensitive technique for the detection of DNA damage. DNA \% in the head, DNA \% in the tail, Comet \%, tail length and tail moment all are considered as important parameters in evaluating the DNA damage. DNA damage assay in liver cells of Clarias gariepinus with a percentage 25.6 in case of fish collected from El-Bats drainage canal and 17.43 for that of fish collected from El-Wadi drainage canal.

\section{Histopathological studies:}

The previous biochemical and physiological investigations were confirmed by histopathological alterations and clear damage of gills, liver and kidneys of the Nile catfish; Clarias gariepinus collected from the different studied aquatic habitats, the main drains at Fayoum governorate (El-Bats and El-Wadi) in comparison with that collected from the river Nile branch at Fayoum sector, El-Lahon.

Gills: The gills of Clarias gariepinus collected from the river Nile branch, El-Lahon are formed of four gill arches on either side of the head and protected externally by the operculum. Each gill arch consists of two hemi-branchs and each hemi-branch is composed of a row of long thin gill filaments (primary gill lamellae). Both sides of each gill filament bear numerous secondary gill lamellae which are the actual site of gas exchange. These lamellae are composed of a thin epithelial cell layer covering pillar cells which, in turn surround the blood sinusoids. At intervals along the layer of epithelial cells there were chloride cells and numerous mucus cells.

Gill sections of fish collected from the different studied sites are shown in Figure 2. Gills of fish collected from the El-Fayoum drainage canals showed clear damage and histopathological changes which include necrosis of epithelial 


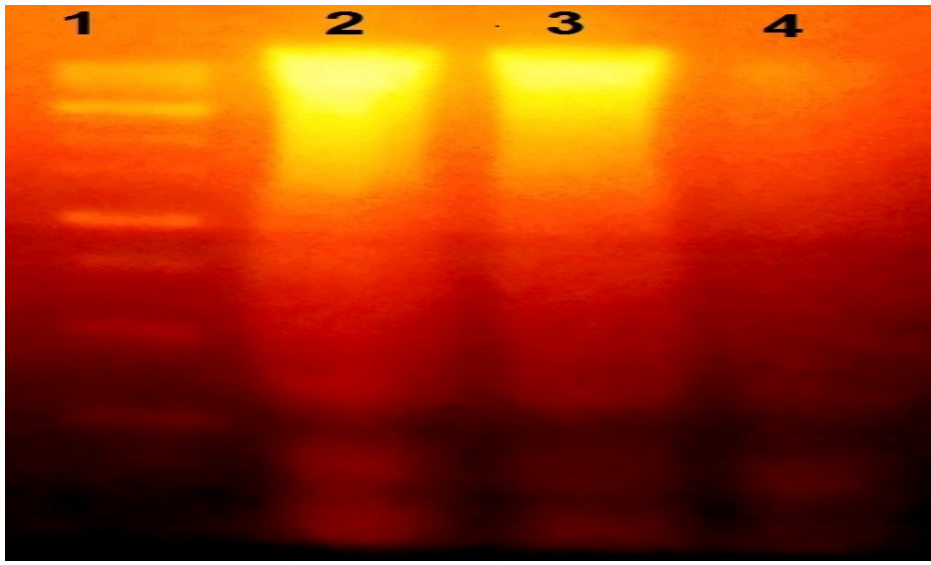

Figure 1. DNA damage assay in liver cells of Clarias gariepinus collected from the river Nile branch (El-Lahon) and the most polluted drainage canals at El-Fayoum governorate (El-Bats and El-Wadi drainage canals), Showing triggered extensive DNA fragmentation in liver cells prior to cell death and lead to activation of an endogenous endonuclease that cleaves double stranded DNA at internucleosomal linker region leading mono- and oligonucleosomes. El-Lahon canal (River Nile Branch) El-Bats drainage canal El-Wadi drainage canal. Studied sites of collection.

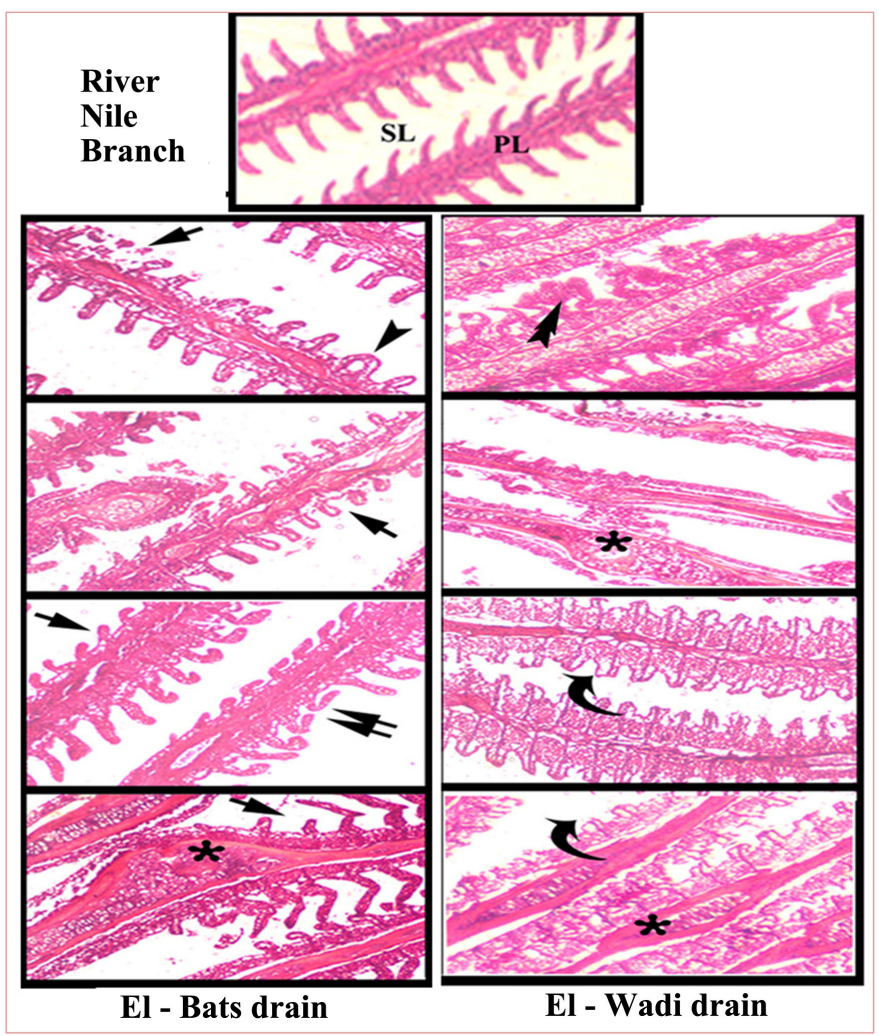

Figure 2. Histological sections in gills of Clarias gariepinus collected from river Nile branch and the main drains at El-Fayoum governorate showing: many secondary lamellae (SL) arising from primary lamellae (PL), and some histopathological lessions in the secondary lamellae such as fusion of the tips of two adjacent SL (arrowhead), or fusion of many SL (double arrow head), degeneration (arrow) dropping (double arrow) desquamation or lefting (bent arrow) and deformation of the cartilagnous skeleton of PL. (HE $\times$ 200). 
Table 5. Comet assay in liver cells of Clarias gariepinus collected from branch of the river Nile and the main drains at El-Fayoum governorate, Egypt.

\begin{tabular}{|c|c|c|c|c|c|c|c|}
\hline Studied Sites of Collection & Tail moment & Tail DNA (\%) & $\begin{array}{l}\text { Tail length } \\
\quad(P X)\end{array}$ & $\begin{array}{l}\text { Head DNA } \\
\quad(\%)\end{array}$ & $\begin{array}{l}\text { Head diameter } \\
\qquad(\mathrm{PX})\end{array}$ & $\begin{array}{c}\text { DNA damage } \\
(\%)\end{array}$ & Intact cells \\
\hline $\begin{array}{c}\text { El-Lahon canal } \\
\text { (Branch of the river Nile) }\end{array}$ & 0.065 & 3.3 & 0.76 & 96.7 & 12.33 & 2.97 & 96.7 \\
\hline El-Bats drainage canal & 1.69 & 36.5 & 4.14 & 63.4 & 13.2 & 25.6 & 74.4 \\
\hline El-Wadi drainage canal & 1.223 & 27.8 & 3.5 & 72.12 & 13.43 & 17.43 & 82.4 \\
\hline
\end{tabular}

cells, epithelial hyperplasia with ballooning degeneration and desquamation of the epithelium.

Liver: Histologically, the liver of Clarias gariepinus collected from the river Nile branch, El-Lahon differs from that of mammals where there is no certain lobular pattern. However, the hepatic parenchyma is arranged radially around the central veins and blood sinusoids are irregularly distributed in the liver tissue. Hepatic cells are polygonal in shape and posses a central spherical or oval nucleus with prominent nucleolus. The nuclei appeared large, and exhibited noticeable variation in diameter from cell to cell. Liver sections of fish collected from the different studied aquatic habitats are shown in Figure 3. Liver sections of fish collected from El-Fayoum drainage canals showed marked histopathological changes with special parenchymal cells and disintegration and necrosis of hepatic cells.

Kidneys: The kidney of the fish collected from the river Nile branch, El-Lahon at Fayoum governorate was characterized by renal tubules surrounded by haemopoietic tissue. Also, glomeruli and renal blood vessels were found between the renal tubules.

Kidney sections of fish collected from the different studied aquatic habitats are shown in Figure 4. Sections of kidney of fish collected from El-Fayoum drainage canals, El-Bats and El-Wadi declared a progressive damage of kidney tubules associated with tubular necrosis, injury of the wall of renal blood vessels and depletion of haemopoietic tissue.

\section{Discussion}

Water quality of the aquatic habitats is considered the main factor controlling the state of health and disease in both cultured and wild fishes [27] [28]. In the present work, assessment of aquatic pollution depended upon physicochemical monitoring to identify and quantify toxicants and to provide data that, for regulatory purposes, could be compared to allowable concentrations in water.

In the present study, the highest water ammonia and nitrite and lowest dissolved oxygen in water samples collected from the studied drainage canals at Fayoum governorate in comparison with samples collected from the river Nile branch could be attributed to agricultural, industrial, and waste municipal effluents which characterized by high load of organic wastes and the microbial 


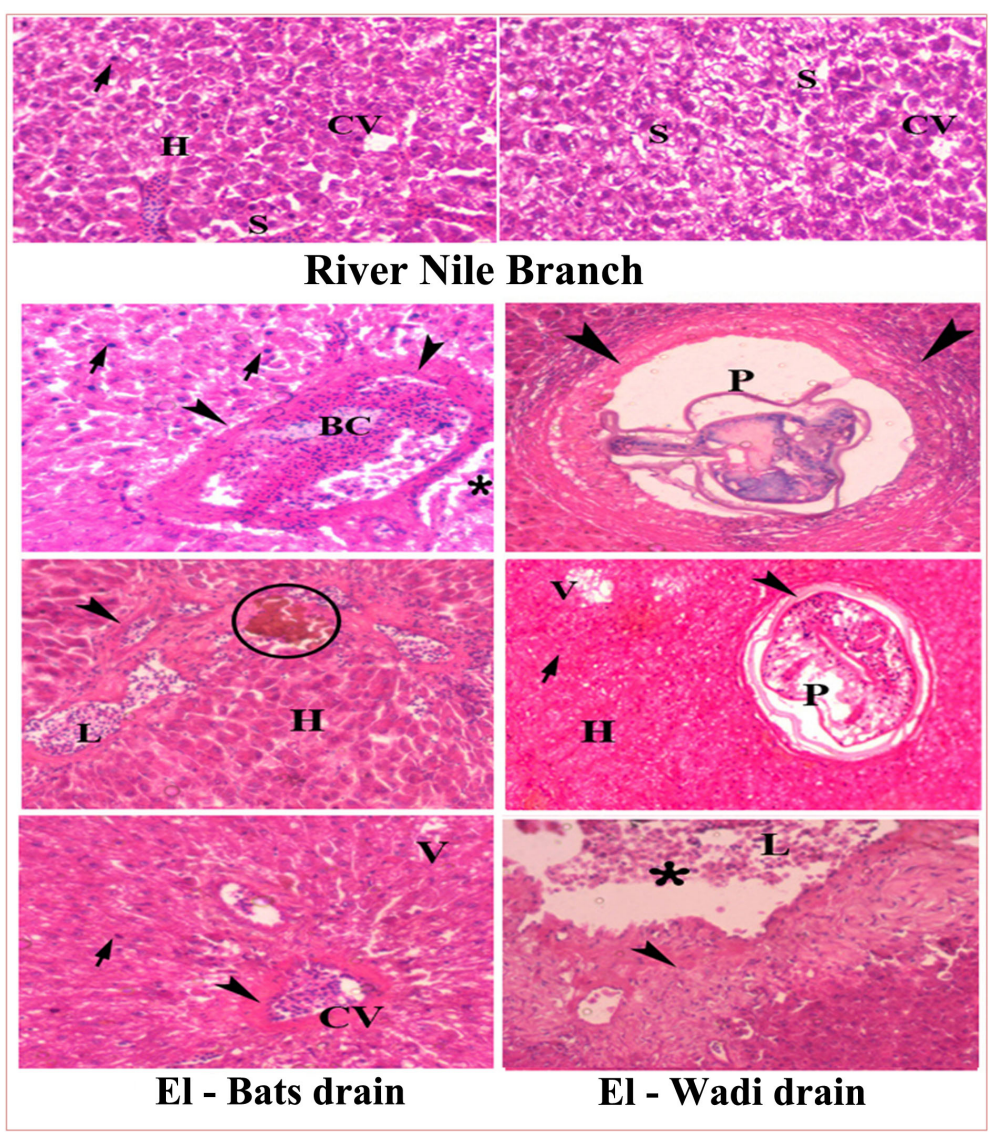

Figure 3. Histological sections in liver of Clarias gariepinus collected from river Nile branch and the main drains at El-Fayoum governorate showing: many liver cells or hepatocytes $(\mathrm{H})$ radiating from central vein $(\mathrm{CV})$, and inclosed many blood sinosoides $(\mathrm{S})$ with kupffer cells. Many histopathological lessions were obseved such as many hepatocyte with pyknotic nuclei (arrow), vacuolated cytoplasm (V), degeneration or necrotic arwea $\left.{ }^{*}\right)$ hemosidrin granules (ring) with leucocytes infiltration (L) and dilated congested central veion. Also, parasites in different stages $(\mathrm{P})$ enclosed by fibrous tissues (arrow head) were noted $(\mathrm{HE} \times 200)$.

activity that degraded the organic matter led to the oxygen consumption. These result may causes a bad impact on the water quality and decrease of dissolved oxygen as a result of oxygen consumption in decomposing organic matter and the oxidation of chemical constituents as previously reported by Ibrahim and Ramzy [29] and Zaghloul et al. [8]. The recorded higher total alkalinity in water of the studied drains at El-Fayoum compared to that collected from the river Nile branch may be attributed to the high content of waste municipal effluents discharged there which maintain the carbonate-bicarbonate buffer system. It may be also due to the increase in phytoplankton density which leads to an increase in photosynthesis that involves the uptake of free carbon dioxide from water and precipitation of calcium carbonate [30] [31].

\section{Residual heavy metals:}

Relative to water, metals are adsorbed on sediment and bioaccumulated in fish affect fish populations, reducing their growth, reproduction and/or survival and 


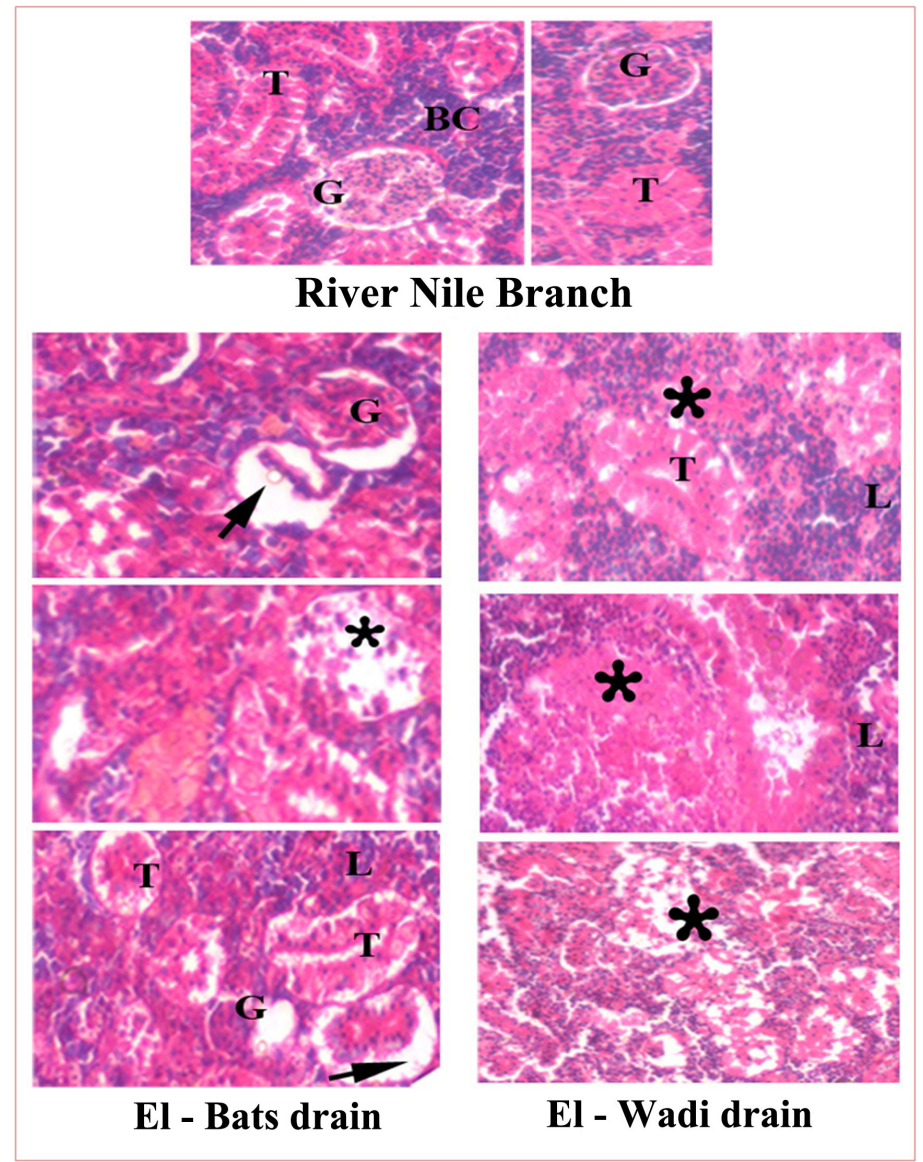

Figure 4. Histological sections in kidney of Clarias gariepinus collected from river Nile branch and the main drains at El-Fayoum governorate showing: Malpighian corpuscle filled with glomerulus $(G)$ and normal kidney tubules lined with epithelial cell (T). Many histopathological lesions were recorded in the fishes of both Wadi and Bats drains such as degeneration or necrosis of large area $\left(^{*}\right)$ with leucocyte infiltration (L). Note degenerated glomerulus and detachment of tubular epithelial cell forming edema (arrow) $(\mathrm{HE} \times 200)$.

may even kill fishes [32]. In the present study, bioaccumulation of metals in tissues varies from metal to metal and among different organs of the same organism that is in accordance with Masoud et al. [33]. Gills are in direct contact with the aquatic medium; therefore, metal concentrations in this organ reflect their concentrations in the external environment. In contrast, the concentrations in liver and kidney represent the rates of bioaccumulation and detoxification of pollutants, as a result concentrations of all studied heavy metals scored highly accumulation pattern, especially in these two organs.

Studied heavy metals concentrations were higher in the gill than in the muscle tissue of the studied fish (Clarias gariepinus). Metal concentration in the gill could be due to the element complexion with the mucus that is impossible to completely remove from the lamellae, before tissue is prepared for analysis. This evidence is in accordance with Heath [34]. Moreover, the low levels of the metals in the muscles may be due to the little blood supply to the muscular tissues as previously confirmed with Osman and Kloas [35]. 


\section{Indicative biochemical Parameters:}

\section{Serum constituents:}

Analysis of serum constituents have proved to be useful in the detection and diagnosis of metabolic disturbance and disease [34]. The use of biochemical and physiological changes of fish have been recommended by several authors for toxicological approaches [36].

Serum constituents of Clarias gariepinus collected from the unpolluted area of the river Nile, El-Lahon branch at El-Fayoum are in the normal ranges as previously reported [37]. However, the reported hyperglycemia in Clarias gariepinus collected from the main drains at El-Fayoum governorate may be due to an enhanced glycogen breakdown in liver, that may be due to the bioaccumulation of the studied heavy metals as revealed in the present study and recorded by Diwan et al. [38]. It is well-established facts that stress stimuli rapid secretion of glucocorticoids and catecholamines from adrenal tissue of the fish. Both hormones are known to produce hyperglycemia in animals [39] [40]. The hyperglycemic condition in this study may be related to secretion of these hormones which causes breakdown of liver glycogen as and the histopathological changes and cells damage in the present study.

Elevations in the activities of serum AST, ALT and ALP in Clarias gariepinus collected from the main drains at Fayoum governorate, El-Wadi and El-Bats drainages reflect hepatic and myocardial impairment, leading to extensive liberation of the enzymes into the blood circulation. Several histopathological alterations have been observed in the liver and kidney of the studied fish (Clarias gariepinus) which support the observed disturbance in the liver function and the increase in serum AST, ALT and ALP activities. The results are in agreement with Al-Attar, [41] who reported that the elevation of serum GOT, GPT and ALP may be due to liver dysfunction. In addition, Mohamed and Gad, [42] reported that the increase of serum GOT; GPT and ALP may be attributed to the hepatocellular damage or cellular degradation, perhaps in liver, heart or muscle. Moreover, Yang and Chen [43] reported that the increase of blood enzymatic activity may be due to increased enzymes synthesis. Increased serum activities of ALP have been explained by pathological processes such as liver impairment, kidney dysfunction and bone disease [43] [44].

Renal failure is usually associated with decrease in urea, uric acid and creatinine excretion, thus leading to its increase in serum. As a result, serum urea, uric acid and creatinine were useful in diagnosis of renal function impairment, renal tubular necrosis, renal insufficient and impaired nitrogen metabolism [45]. The increased blood uric acid and creatinine of Clarias gariepinus collected from El-Bats and El-Wadi drainages when compared with that of fish collected from the river Nile branch, El-Lahon channel may be attributed to gill dysfunction as aresult of gills structure damage in the present study. Moreover, kidney damage may result in reduced renal blood flow with reduction in glomerular filtration rate, resulting in azotemia characterized by increase in uric acid and creatinine. Similar increase in plasma urea, uric acid and creatinine were previously rec- 
orded by El-Boshy and Taha [46] in case of Nile tilapia exposed to mercuric chloride.

In the present study, several histopathological alterations have been observed in the gills, liver and kidney of Clarias gariepinus collected from the most polluted main drains at Fayoum governorate, El-Bats and El-Wadi which support the observed disturbances in all studied serum constituents.

Total plasma proteins play an important role in the metabolism and regulation of water balance. The normal range of plasma total protein concentration in fish $(4.08 \pm 0.61 \mathrm{~g} / \mathrm{dl})$ that reported by Sabae and Mohamed, [4]. So any disturbances make this reading up or down more useful in diagnosis of fish disease. The majority of plasma proteins which are synthesized in the liver, is used as an indicator of liver impairment as that mentioned by Yang and Chem [43]. In the present study, there was elevation in serum total protein (hyperproteinaemia), albumin and globulin in the studied fish, Clarias gariepinus collected from ElBats and El-Wadi drainage canals when compared with that of fish collected from the branch of the rive Nile, El-Lahon channel at Fayoum governorate which were within range. This possibly due to activation of metabolic systems in response to pollutants exposure, degradation of the cellular material in the liver, several pathological conditions as damage of liver and kidney, as shown in the present study and relative changes in the mobilization of blood proteins, water loss in the plasma and/or induction of protein synthesis in liver as previously reported [41].

\section{Genotoxicity: Evaluation of DNA damage:}

Genotoxic biomarker, DNA fragmentation, was used to evaluate the complex metals genotoxic effects in the studied aquatic habitats at the DNA level in liver cells (the detoxification organ) of the studied fish species; Clarias gariepinus. The comet assay has been demonstrated to be a powerful tool for measuring the relationship between DNA damage and the exposure of aquatic organisms to genotoxic pollutants on environmental as that mentioned by Fatima, et al., [47]. In the present assay, we found that the DNA strand breaks in fish liver cells increased statistically in Clarias gariepinus collected from El-Bats and El-Wadi drainage canals compared to fish collected from El-Lahon branch of the river Nile at El-Fayoum governorate, and this damage represented in terms of percent cells with tail, tail length, and percent DNA in tail. In agreement with this study, comet fish exposed sub chronically and chronically to effluents from a Swine industry associated with greater DNA damage [48].

DNA of the liver cells of Clarias gariepinus collected from the highly polluted drainage canals showed signs of internucleosomal fragmentation as evidenced by a ladder pattern caused by cleavage of DNA into segments which is considered as hallmark of apoptosis. Internucleosomal fragmentation was also accompanied by some random fragmentation as detected by an overlying continuous smear of DNA which is considered as hallmark of necrosis.

Liver as an active metabolic organs which can accumulate more metals than 
other tissues. Accumulated heavy metals in tissues of fish may catalyze reactions that generate ROS which may lead to environmental oxidative stress [49]. Metal catalyzed formation of ROS is capable of damaging tissue macromolecules such as DNA, proteins and lipids [50]. These free radicals could activate the mitochondrial membrane permeability transition pore, which leads to rupture of the outer membrane of the mitochondria and release of substances such as apoptosis-inducing factor and cytochrome $\mathrm{c}$ that produce apoptotic cell death [51]. Another mechanism is that ROS stimulate endogenous endonuclease activity [49]. Degradation of internucleosomal DNA segments as a consequence of activation of endogenous endonucleases is considered a characteristic end point of apoptosis [7] and necrosis [52].

Nevertheless, the present investigation showed mixed smearing and laddering of DNA fragments which is most probably attributed to the nonspecific DNA fragmentation process encountered with apoptosis. This observation is in agreement with Razzaque [53] who stated that both fragmentation patterns may involve more than one mechanism of cell death and the combined effects of these events can induce apoptosis and/or necrotic cell death.

\section{Histopathological studies:-}

Histopathological evaluation as a category of biomarkers allows examining specific target organs, including gills, kidney and liver that are responsible for vital functions, such as respiration, excretion and the accumulation and biotransformation of xenobiotic in the fish as previously reported [11] [54].

\section{Histopathological alterations of gills:}

Owing to their direct and continuous contact with the external medium and their functions in respiratory gas exchange, osmoregulation, excretion of nitrogenous waste products and acid-base regulation, this organ is directly affected by contaminants [55] [59].

The most common histopathological alteration detected was the epithelial desquamation (separation or lifting) from the base towards the tips of most respiratory lamellae. Lifting of the secondary lamellar epithelium due to hypertrophy are the first signs that gills have been exposed to hazardous chemicals, or physical agents may have been a response to increase the diffusion distance between dissolved oxygen and blood, which accordingly was related to hypoxia in fish. Lamellar fusion, hyperplasia and necrosis of different lamellar and filament cells like chloride and pavement cells is another most commonly reported change, but is more common for metals than for organics or other pollutants, possibly since metals directly interact with ion transport proteins and inhibit their activity as previously noticed [54] [56].

\section{Histopathological alterations of liver:}

Microscopic examination of the liver of fish collected from the river Nile branch showed a normal structure with compactly arranged hepatocytes, sinusoids were scattered randomly in between the hepatocytes and the hepatocytes had uniform morphology along with central vein. Also, a typical parenchymal appearance at 
light microscopical level and hepatocytes with polygonal shape, central spherical and densely stained nuclei were seen.

Liver sections of fish collected from the ecological disturbed aquatic habitats (the main drains at Fayoum governorate) showed marked histopathological changes including vacuolar degeneration, infiltration of red blood cells through the hepatocytes with congestion, vacuolar structures, dilated intercellular space, karyomegaly (dark and condensed nuclei), degeneration in pancreatic tissue, peliosis (replacement of liver tissue with blood-filled cavities without an endothelial cell lining), loss of cord structure, infiltration of inflammatory cells, damage of parenchymal cells, cloudy swelling and tissue disorientation with rupture of parenchyma cells and single cell necrosis. These findings are in agreement with several authers [57] [58]. This histological change in liver tissues is thought to be a response of Kupffer cells (responsible for detoxification) to various pollutants and these results coincided with Koca et al. [59].

\section{Histopathological alterations of kidney:}

The normal kidney samples showed uniformly functional units (renal tubules) and the interstices of the tubules contain haematopoietic tissues. In contrast, the common lesion found in the kidney of fish collected from El-Bats and El-Wadi drains (main drains at Fayoum governorate) was glomerular shrinkage, glomerular splitting, Tubular degeneration and necrosis. Tubular epithelial cell separated from basement membrane resulting from edema. There was also some evidence of melanomacrophages aggregation accompanied with congestion and haemorrhage, glomerular shrinkage with increase in Bowman's space, periglomerular oedema and glomerular necrosis. The evident alterations were previously [60] in case of white sea bass (Lates calcarifer). These results indicate that heavymetal contamination definitely affects structural and functional attributes of fish kidney. Moreover, degeneration of tubular epithelial cells and tubular necrosis may be due to the accumulation of inflammatory cells associated with metals toxicity [1]. These changes may be also attributed to impaired blood supply due to toxic action of different pollutants including heavy metals, especially cadmium which is known as renal toxicity as previously mentioned [11] [61]. To sum up, this histological endpoint showed severe injuries and damages in all studied tissues suggesting too slow defense mechanisms in these tissues to immobilize or eliminate heavy metals demonstrating the sensitivity of fish cells to metals exposure.

One could conclude that, preserving the environment is not an entertainment or luxury any more, yet it became crucial to protect our resources for the coming generations. Moreover, protecting the environment is a national duty and laws shall regulate the procedures of keeping good environment.

\section{Conflicts of Interest}

The authors declare no conflicts of interest regarding the publication of this paper. 


\section{References}

[1] Velma, V. and Tchounwou, P.B. (2010) Chromium-Induced Biochemical, Genotoxic and Histopathological Effects in Liver and Kidney of Goldfish. Mutation Research/Genetic Toxicology and Environmental Mutagenesis, 698, 43-51. https://doi.org/10.1016/j.mrgentox.2010.03.014

[2] Anghel, A.-M., Ilie, M., Ghita, G., Marinescu, F. and György, D. (2017) Assessing the Aquatic Environment Quality Contaminated with Heavy Metals as a Result of Poly metallic Mining in the North West Region of Romania Using Pollution Indices. International Journal of Environmental Science and Development, 8, 111-115. https://doi.org/10.18178/ijesd.2017.8.2.931

[3] Authman, M.M.N. and Abbas, H.H.H. (2007) Accumulation and Distribution of Copper and Zinc in Both Water and Some Vital Tissues of Two Fish Species (Tilapia zillii and Mugil cephalus) of Lake Qarun, Fayoum Province, Egypt. Pakistan Journal of Biological Sciences, 10, 2106-2122. https://doi.org/10.3923/pjbs.2007.2106.2122

[4] Sabae, S.Z. and Mohamed, F.A.S. (2015) Effect of Environmental Pollution on the Health of Tilapia spp. from Lake Qarun. Global Veterinaria, 14, 304-328.

[5] El-Sherif, S.A. and Abd El-Ghafour, S. (2016) Investigation of Quality Properties and Nutritional Values of Four Fish Species from Lake Qaroun, Egypt. International Journal of ChemTech Research, 9, 16-26.

[6] Konsowa, A.H. (2007) Ecological Studies on Fish Farms of El-Fayoum Depression (Egypt). Egyptian Journal of Aquatic Research, 33, 290-300.

[7] Rahman, Q., Lohani, M., Dopp, E., Pemsel, H., Jonas, L., Weiss, D.G. and Schiffmann, D. (2002) Evidence That Ultrafine Titanium Dioxide Induces Micronuclei and Apoptosis in Syrian Hamster Embryo Fibroblasts. Environmental Health Perspectives, 110, 797-800. https://doi.org/10.1289/ehp.02110797

[8] Zaghloul, K.H., Said, A.A., El-Sayad, S.M. and Ali, G.S. (2016) Assessment of Fish Farms Water Quality on the Cultured. Oreochromis niloticus and Mugil cephalus at El-Fayoum Governorate Egypt. Egyptian Journal of Zoology, 66, 151-166.

[9] Goher, M.E., Abdo, M.H., Bayoumy, W.A. and Mansour El-Ashkar, T.Y. (2017) Some Heavy Metal Contents in Surface Water and Sediment as Pollution Index of El-Manzala Lake, Egypt. Journal of Basic and Environmental Sciences, 2, 210-225.

[10] Fathi, A.A. and Flower, R.J. (2005) Water Quality and Phytoplankton Communities in Lake Qarun (Egypt). Aquatic Sciences, 67, 350-362.

https://doi.org/10.1007/s00027-005-0777-2

[11] Abdel-khalek, A.A., Elhaddad, E., Mamdouh, S. and Marie, M.A.S. (2016) Assessment of Metal Pollution around Sabal Drainage in River Nile and Its Impacts on Bioaccumulation Level, Metals Correlation and Human Risk Hazard Using Oreochromis niloticus as a Bioindicator. Turkish Journal of Fisheries and Aquatic Sciences, 16, 227-239.

[12] David, M., Ramesh, H., Patil, V., Marigoudar, S. and Chebbi, S. (2010) Sodium Cyanide-Induced Modulations in the Activities of Some Oxidative Enzymes and Metabolites in the Fingerlings of Cyprinus carpio (Linnaeus). Toxicological and Environmental Chemistry, 92, 1841-1849. https://doi.org/10.1080/02772248.2010.498374

[13] Arya, A. (2014) Evaluation of Biochemical and Histochemical Changes Following the Combined Treatment of Mercury and Cadmium in a Fresh Water Cat Fish, Clarias Batrachus. International Journal of Pharmacy and Pharmaceutical Sciences, 6, 356-358. 
[14] Ohe, T., Watanabe, T. and Wakabayashi, K. (2004) Mutagens in Surface Waters: A Review. Mutation Research/Reviews in Mutation Research, 567, 109-149. https://doi.org/10.1016/j.mrrev.2004.08.003

[15] Paithane, K.T., Sonawane, D.L., Bhandare, R.Y. and More, P.R. (2012) Histophatological Changes Due to Induced Dimethoate in the Liver of Freshwater Fish Channa punctatus from River Shivana, Aurangabad (M.S) India. The Ecoscan, 1, 213-217.

[16] Ndimele, P.E. and Kumolu-Johnson, C.A. (2012) Some Aspects of the Physic Chemistry and Heavy Metal Content of Water, Sediment and Cynothrissa mento (Regan, 1917) from Badagry Creek, Lagos, Nigeria. Trends in Applied Sciences Research, 7, 724-736. https://doi.org/10.3923/tasr.2012.724.736

[17] American Public Health Association (2005) Standard Methods for the Examination of Water \& Wastewater. American Public Health Association, Washington DC.

[18] Trinder, P. (1969) Enzymatic Colorimetric Method of Glucose. Annals of Clinical Biochemistry, 6, 24-27. https://doi.org/10.1177/000456326900600108

[19] Reitman, S. and Frankel, S. (1957) A Colorimetric Method for the Determination of Serum Glutamic Oxaloacetic and Glutamic-Pyruvic Transaminases. American Journal of Clinical Pathology. 28, 56-63. https://doi.org/10.1093/ajcp/28.1.56

[20] Tietz, N.W., Rinker, A. and Shaw, L. (1983) IFCC Methods for the Measurements of Catalytic Concentration of Enzymes. Part 5. IFCC Method for Alkaline Phosphatase. Journal of Clinical Chemistry and Clinical Biochemistry, 21, 731-748.

[21] Tietz, N.W. (1986) Textbook of Clinical Chemistry. W.B. Saunders Co., Philadelphia, 1271-1281.

[22] Tietz, N.W. (1990) Clinical Guide to Laboratory Tests. 2nd Edition, W.B. Saunders Co., Philadelphia, 566.

[23] King, E.J. and Wootton, I.D.P. (1959) Determination of Total Protein. Micro-Analysis in Medical Biochemistry. Churchill, London.

[24] Doumas, B., Watson, W. and Biggs, H. (1971) Albumin Standard and the Measurement of Serum Albumin with Bromo Cresol Green. Clinica Chimica Acta, 31, 87-96. https://doi.org/10.1016/0009-8981(71)90365-2

[25] Kumaravel, T. and Jha, A.N. (2006) Reliable Comet Assay Measurements for Detecting DNA Damage Induced by Ionising Radiation and Chemicals. Mutation Research/Genetic Toxicology and Environmental Mutagenesis, 605, 7-16. https://doi.org/10.1016/j.mrgentox.2006.03.002

[26] SAS Institue Inc. (2000) Statistical Analysis, SAS/STAT User's Guide. Version 6.2, SAS Institute Inc., Cary.

[27] Poonam, T., Tanushree, B. and Sukalyan, C. (2013) Water Quality Indices-Important Tools for Water Quality Assessment: A Review. International Journal of Advanced Chemistry, 1, 15-28.

[28] Jia, Y.Y., Wang, L., Cao, J.F., Li, S. and Yang, Z.G. (2018) Trace Elements in Four Freshwater Fish from a Mine-Impacted River: Spatial Distribution, Species-Specific Accumulation, and Risk Assessment. Environmental Science and Pollution Research, 25, 8861-8870. https://doi.org/10.1007/s11356-018-1207-z

[29] Ibrahim, L.A. and Ramzy, E.M. (2013) Water Quality and Its Impact on Tilapia zilli (Case Study) Qarun Lake-Egypt. International Water Technology Journal, 3, 170-191.

[30] Boyd, C.E. (1990) Water Quality in Ponds for Aquaculture. Birmingham Publishing Co., Birmingham.

[31] Kumar, M.S., Binh, T.T., Burgess, S.N. and Luu, L.T. (2005) Evaluation of Optimal Species Ratio to Maximize Fish Polyculture Production. Journal of Applied Aqua- 
culture, 17, 35-49. https://doi.org/10.1300/J028v17n01_03

[32] Abadi, D.R.V., Dobaradaran. S., Nabipour, I., Lamani, X., Ravanipour, M., Tahmasebi, R. and Nazmara, S. (2015) Comparative Investigation of Heavy Metal, Trace, and Macro Element Contents in Commercially Valuable Fish Species Harvested Off from the Persian Gulf. Environmental Science and Pollution Research, 22, 66706678. https://doi.org/10.1007/s11356-014-3852-1

[33] Masoud, M.S., El-Samra, M.I. and El-Sadawy, M.M. (2007) Heavy-Metal Distribution and Risk Assessment of Sediment and fish from El Mex Bay, Alexandria, Egypt. Chemistry and Ecology, 23, 201-216. https://doi.org/10.1080/02757540701339760

[34] Heath, A.G. (1995) Water Pollution and Fish Physiology. 2nd Edition, Lewis Publisher. New York and London, 359.

[35] Osman, A.G.M. and Kloas, W. (2010) Water Quality and Heavy Metal Monitoring in Water, Sediments and Tissues of the African Catfish Clarias gariepinus (Burchell, 1822) from the River Nile, Egypt. Journal of Environmental Protection, 1, 389-400. https://doi.org/10.4236/jep.2010.14045

[36] Zaghloul, K.H., Said, A.A., El-Sayad, S.M. and Ali, G.S. (2016) Role of Heavy Metals Bioaccumulation on Some Physiological and Histopathological Changes in the Cultured Oreochromis niloticus and Mugil cephalus at El-Fayoum Governorate, Egypt. Egyptian Journal of Zoology, 66, 167-188. https://doi.org/10.12816/0034716

[37] Haggag, A.M., Marie, M.A.S. and Zaghloul, K.H. (1999) Seasonal Effects of the Industrial Effluents on the Nile Catfish. Clarias gariepinus. Journal of the EgyptianGerman Society of Zoology, 28, 365-392.

[38] Diwan, A.D., Hingorani, H.G. and Chandrasekhram naidu, N. (1979) Levels of Blood Glucose and Tissue Glygogen in Two Live Fish Exposed to Industrial Effluents. Bulletin of Environmental Contamination and Toxicology, 21, 269-272. https://doi.org/10.1007/BF01685422

[39] Mazeaud, M.M., Mazeaud, F. and Donaldson, E.M. (1977) Primary and Secondary Effects of Stress in Fish, Some New Data with a General Review. Transactions of the American Fisheries Society, 106, 201-212. https://doi.org/10.1577/1548-8659(1977)106<201:PASEOS>2.0.CO;2

[40] Pickering, A.D. (1981) Stress and Compensation in Teleostean Fishes. Response to Social and Physical Factors. In: Pickering, A.D., Ed., Stress and Fish, Academic Press, New York, London, 295-322.

[41] Al-Attar, A.M. (2005) Biochemical Effects of Short-Term Cadmium Exposure on the Freshwater Fish, Oreochromis niloticus. Journal of Biological Sciences, 5, 260-265. https://doi.org/10.3923/jbs.2005.260.265

[42] Mohamed, F.A.S. and Gad, N.S. (2009) Bioaccumulation, Some Blood Biochemical Changes and Histological Alterations in Selected Tissues of Oreochromis niloticus Exposed to Zinc and/or Cadmium. American-Eurasian Journal of Agricultural \& Environmental Sciences, 5, 441-455.

[43] Yang, J.L. and Chen, H.C. (2003) Serum Metabolic Enzyme Activities and Hepatocytes Ultra Structure of Common Carp after Gallium Exposure. Zoological Studies, 42, 455-461.

[44] Frat, O., Cogun, H., Yuzereroglu, T., Gok, G., Rat, O.F., Kargin, F. and Kotemen, Y. (2011) A Comparative Study on the Effects of a Pesticide (Cypermethrin) and Two Metals (Copper, Lead) to Serum Biochemistry of Nile Tilapia, Oreochromis niloticus. Fish Physiology and Biochemistry, 37, 657-666. https://doi.org/10.1007/s10695-011-9466-3

[45] Murray, R., Mayes, P., Granner, D. and Radwel, V. (1990) Harper's Biochemistry? 
22nd Edition, Appleton and Lange, London, Toronto.

[46] El-Boshy, M. and Taha, R. (2011) Effects of Mercuric Chloride on the Immunological, Hematological, Biochemical Parameters and Diseases Resistance of Nile Tilapia Challenged with Aeromnas hydrophila. Nature and Science, 9, 7-15.

[47] Fatima, M., Usmani, N., Mobarak Hossain, M., Siddiqui, M.F., Zafeer, M.F., Firdaus, F. and Ahmad, S. (2014) Assessment of Genotoxic Induction and Deterioration of Fish Quality in Commercial Species Due to Heavy-Metal Exposure in an Urban Reservoir. Archives of Environmental Contamination Toxicology, 67, 203-213. https://doi.org/10.1007/s00244-014-0024-8

[48] Lima, P.L., Benassi, J.C., Pedrosa, R.C., Dal Magro, J., Oliveiraand, T.B. and Wilhelm Filho, D. (2006) Time-Course Variations of DNA Damage and Biomarkers of Oxidative Stress in Tilapia (Oreochromis niloticus) Exposed to Effluents from a Swine Industry. Archives of Environmental Contamination Toxicology, 50, 23-30. https://doi.org/10.1007/s00244-004-0178-x

[49] Farombi, E.O., Adelowo, O.A. and Ajimoko, Y.R. (2007) Biomarkers of Oxidative Stress and Heavy Metal Levels as Indicators of Environmental Pollution in African Catfish (Clarias gariepinus) from Nigeria Ogun River. International Journal of Environmental Research and Public Health, 4, 158-165.

https://doi.org/10.3390/ijerph2007040011

[50] Pandey, S., Parvez, S., Sayeed, I., Haque, R., Bin-Hafeez, B. and Raisuddin, S. (2003) Biomarkers of Oxidative Stress: A Comparative Study of River Yamuna Fish Wallago attu (Bl. \& Schn.). Science of The Total Environment, 309, 105-115. https://doi.org/10.1016/S0048-9697(03)00006-8

[51] Kroemer, G. (1997) The Proto-Oncogene Bcl-2 and Its Role in Regulating Apoptosis. Nature Medicine, 3, 614-620. https://doi.org/10.1038/nm0697-614

[52] Higuchi, M., Honda, T., Proske, R.J. and Yeh, E.T. (1998) Regulation of Reactive Oxygen Species-Induced Apoptosis and Necrosis by Caspase 3-Like Proteases. Oncogene, 17, 2753-2760. https://doi.org/10.1038/sj.onc.1202211

[53] Razzaque, M.S. (2007) Cisplatin Nephropathy: Is Cytotoxicity Avoidable? Nephrology Dialysis Transplantation, 22, 2112-2116. https://doi.org/10.1093/ndt/gfm378

[54] Reddy, P.B. and Rawat, S.S. (2013) Assessment of Aquatic Pollution Using Histopathology in Fish as a Protocol. International Research Journal of Environment Sciences, 2, 79-82.

[55] Bhagwant, S. and Elahee, K.B. (2002) Pathologic Gill Lesions in Two Edible Lagoon Fish Species, Mulloidichthys flavolineatus and Mugil cephalus, from the Bay of Poudre d'Or, Mauritius. Western Indian Ocean Journal of Marine Science, 1, 35-42.

[56] Butchiram, M.S., Vijaya Kumar, M. and Tilak, K.S. (2013) Studies on the Histopatholoigcal Changes in Selected Tissues of Fish Labeo rohita to Phenol. Journal of Environmental Biology, 34, 247-251.

[57] Abou El-Gheit, E.N., Abdo, M.H. and Mahmoud, S.A. (2012) Impacts of Blooming Phenomenon on Water Quality and Fishes in Qaroun Lake, Egypt. International Journal of Environmental science and Engineering, 3, 11-24.

[58] Omar, W.A., Zaghloul, K.H., Abdel-Khalek, A.A. and Abo-Hegab, S. (2013) Risk Assessment and Toxic Effects of Metal Pollution in Two Cultured and Wild Fish Species from Highly Degraded Aquatic Habitats. Archives of Environmental Contamination and Toxicology, 65, 753-764. https://doi.org/10.1007/s00244-013-9935-Z

[59] Koca, Y.B.M., Koca, S., Yildiz, S., Gurcu, B., Osanc, E., Tuncbas, O., et al. (2005) Investigation of Histopathological and Cytogenetic Effects on Lepomis gibbosus (Pisces. Perciformes) in the Cine Stream (Aydin/Turkey) with Determination of 
Water Pollution. Environmental Toxicology, 20, 560-571.

https://doi.org/10.1002/tox.20145

[60] Thophon, S., Kruatrachue, M.U., Pokethitiyook, E.S., Sahaphong, P.S. and Jaritkhuan, S. (2003) Histopathological Alterations of White Seabass, Lates calcarifer in Acute and Subchronic Cadmium Exposure. Environmental Pollution, 121, 307-320. https://doi.org/10.1016/S0269-7491(02)00270-1

[61] Yancheva, V., Velcheva, I., Stoyanova, S. and Georgieva, E. (2015) Histological Biomarkers in Fish as a Tool in Ecological Risk Assessment and Monitoring Programs. Applied Ecological and Environmental Research, 14, 47-75.

https://doi.org/10.15666/aeer/1401_047075 